\title{
Comparative analysis of the frequency and the severity of diagnosed lesions between pedestrians struck by motor vehicles and other blunt trauma mechanisms victims
}

\section{Análise comparativa das lesões diagnosticadas e de sua gravidade entre vítimas de atropelamento e outros mecanismos de trauma fechado}

José Gustavo Parreira, TCBC-SP1; Rafael Krieger Martins²; Julio Slongo²; Jacqueline A. Giannini Perlingeiro, TCBC-SP1; Silvia Cristine Soldá, TCBC-SP; José Cesar Assef, TCBC-SP1

\section{A B S S T R A C T}

\begin{abstract}
Objective: to compare the frequency and the severity of diagnosed injuries between pedestrians struck by motor vehicles and victims of other blunt trauma mechanisms. Methods: retrospective analysis of data from the Trauma Registry, including adult blunt trauma patients admitted from 2008 to 2010. We reviewed the mechanism of trauma, vital signs on admission and the injuries identified. Severity stratification was carried using RTS, AIS-90, ISS e TRISS. Patients were assigned into group A (pedestrians struck by motor vehicle) or B (victims of other mechanisms of blunt trauma). Variables were compared between groups. We considered p<0.05 as significant. Results: a total of 5785 cases were included, and $1217(21,0 \%)$ of which were in group A. Pedestrians struck by vehicles presented $(p<0.05)$ higher mean age, mean heart rate upon admission, mean ISS and mean AIS in head, thorax, abdomen and extremities, as well as lower mean Glasgow coma scale, arterial blood pressure upon admission, RTS and TRISS. They also had a higher frequency of epidural hematomas, subdural hematomas, subarachnoid hemorrhage, brain swelling, cerebral contusions, costal fractures, pneumothorax, flail chest, pulmonary contusions, as well as pelvic, superior limbs and inferior limbs fractures. Conclusion: pedestrian struck by vehicles sustained intracranial, thoracic, abdominal and extremity injuries more frequently than victims of other blunt trauma mechanism as a group. They also presented worse physiologic and anatomic severity of the trauma.
\end{abstract}

Key words: Accidents, Traffic. Multiple Trauma. Trauma Severity Indices. Accident Prevention. Wounds and Injuries.

\section{INTRODUCTION}

$\mathrm{R}^{\mathrm{s}}$ oad vehicle accidents are a major public health problem worldwide. Such accidents constitute the eighth leading cause of death, accounting for 1.24 million fatalities per year ${ }^{1}$. Road accidents are the leading cause of death among young individuals aged $15-29$ years. The majority of these deaths occur in underdeveloped or developing countries $^{2}$.

Pedestrians account for $22 \%$ of victims of road accidents globally and $20 \%$ in Brazil2,3. Brazilian mortality rates in this subgroup have remained constant (at around 20 deaths per 100,000 persons), despite a more than $200 \%$ increase in the fleet of vehicles in the past 15 years (DENATRAN) ${ }^{4}$. According to data from DATASUS, the number of pedestrian deaths remained at a relatively stable absolute rate over the past decade $(9,000-10,000$ deaths/year) but has declined proportionally:from $36 \%$ in
1998 to $20 \%$ in 2011 , explained by the fact that motorcyclists and cyclists now represent a larger proportion of overall traffic-related deaths ${ }^{3,5}$. The most common lesions in individuals struck by vehicles are musculoskeletal and head injuries, depending on the population studied ${ }^{6,7}$. According to Hefny et al., in 2014, the main cause of death was severe traumatic brain injuries ${ }^{8}$. Few studies have investigated long-term sequelae in this patient group. The disability rate is believed to be high but national data remains scarce.

A search of the available literature revealed no studies comparing the rate and severity of injuries among pedestrians struck by vehicles versus patients with other mechanisms of blunt trauma.This data could be valuable in assisting first-responders to establish adequate triage procedures and promoting more rational use of complementary exams, allocating the resources available to the treatment of these patients. The

1. Disciplina de Cirurgia de Urgência. Departamento de Cirurgia. Faculdade de Ciências Médicas da Santa Casa de São Paulo - SP - Brasil; 2. Departamento de Cirurgia. Irmandade da Santa Casa de Misericórdia de São Paulo - SP - Brasil. 
objective of the present study was to compare the rate and severity of injuries diagnosed in pedestrians struck by vehicles versus patients with other mechanisms of blunt trauma.

\section{METHODS}

A retrospective analysis of the information stored on the database of the emergency service was carried out based on data collected prospectively from a trauma registry for quality control between 2008 and 2010. All blunt trauma patients older than 13 years of age admitted to the emergency service were selected for the analysis. This study was submitted to the Research Ethics Committee of the institution and approved under process number 914.477.

Information was collected on trauma mechanism, vital-signs on admission, complementary exams performed, injuries diagnosed, along with their severity and management. Severity of the sample was stratified using the following trauma indexes: Revised Trauma Score (RTS), Abbreviated Injury Scale 1990 (AIS) ${ }^{10}$, Injury Severity Score (ISS) ${ }^{11}$ and probability of survival calculated by the TRISS method $^{12}$. Severe injuries were defined as those with AIS $>3$ in the different body segments.

Trauma patients were split into two groups: Group A- pedestrians struck by motor vehicles; Group B- patients with other mechanisms of blunt trauma, including motorcyclists involved in road traffic accidents, occupants of four-wheeled vehicles, falls, physical assault, cyclists and associated mechanisms.

Variables for the two groups were compared to identify the specific characteristics of pedestrians struck by vehicles. The statistical analysis was performed using the Chi-square or Fisher's exact tests for qualitative variables and Student's $t$-test and Mann-Whitney test for quantitative variables, according to the distribution of the sample. A value of $p<0.05$ was considered significant.

\section{RESULTS}

Data from 5,785 blunt trauma patients was included in the study. Mean age of patients was $39.3 \pm 17.1$ years. The most common trauma mechanisms were: accidents involving motorcyclists, being struck by a road vehicle, falls from the same level, falls from height, physical assault, automobile accidents involving occupants of fourwheeled vehicles and associated mechanisms (Table 1). The means and standard deviations on the RTS, ECG, ISS and TRISS indexes for the sample analyzed were: 7.6 60.9 , $14.6 \pm 2,4.6 \pm 8$, and $0.99 \pm 0.4$, respectively. Comparison of the groups showed that pedestrians struck by vehicles had significantly $(p<0.05)$ greater mean age, mean heart rate on admission, lower mean Glasgow coma scale, systolic arterial pressure on admission, lower arterial hemoglobin saturation (pulse oximetry) on admission a greater mean AIS in the head, thorax, abdomen and in extremities segments (Table 2). With regard to the trauma scales, Group A patients had a higher mean score on the ISS, and lower mean score on both the RTS and the TRISS (Table 2).

Group A patients had a significantly $(p<0.05)$ higher rate of extradural hematomas, acute subdural hematomas, traumatic subarachnoid hemorrhage, brain contusion, diffuse axonal injury, brain swelling, hemothorax, rib fractures, pneumothorax, flail chest, lung contusion, pelvic fractures, upper limb fractures, lower limb fractures and lower limb open fractures (Table 3). Also in Group A, a greater need for orotracheal intubation (5.3\% vs. $2.3 \%$ ) and closed chest drainage on admission ( $2.7 \%$ vs. $1.3 \%$ ) $(p<0.05)$ were noted. Lethality was significantly higher in Group A (4.3\% vs. 1.5\%).

\section{DISCUSSION}

Vehicle-pedestrian accidents result from a variety of different factors. Many of these factors are associated with local conditions and others with individual behavior. Signage conditions at the scene of the accident are directly

Table 1 - Trauma mechanism.

\begin{tabular}{lrr}
\hline Trauma mechanism & Number & $\%$ \\
\hline Motorcyclists & 1390 & $24 \%$ \\
Struckbyvehicle & 1217 & $21 \%$ \\
Fall from the same level & 997 & $17.2 \%$ \\
Fall from height & 734 & $12.7 \%$ \\
Physical assault & 646 & $11.2 \%$ \\
Driver or passenger of four-wheeled automobile & 552 & $9.5 \%$ \\
Associated mechanisms & 249 & $4.3 \%$ \\
TOTAL & 5785 & $100 \%$ \\
\hline
\end{tabular}

Source: Serviço de Emergência da Irmandade da Santa Casa de Misericórdia de São Paulo (2008-2013). 
Table 2 - Comparison of quantitative variables for Group A (pedestrians struck by vehicle) versus Group B (patients with other mechanisms of blunt trauma).Data expressed as mean/standard deviation.

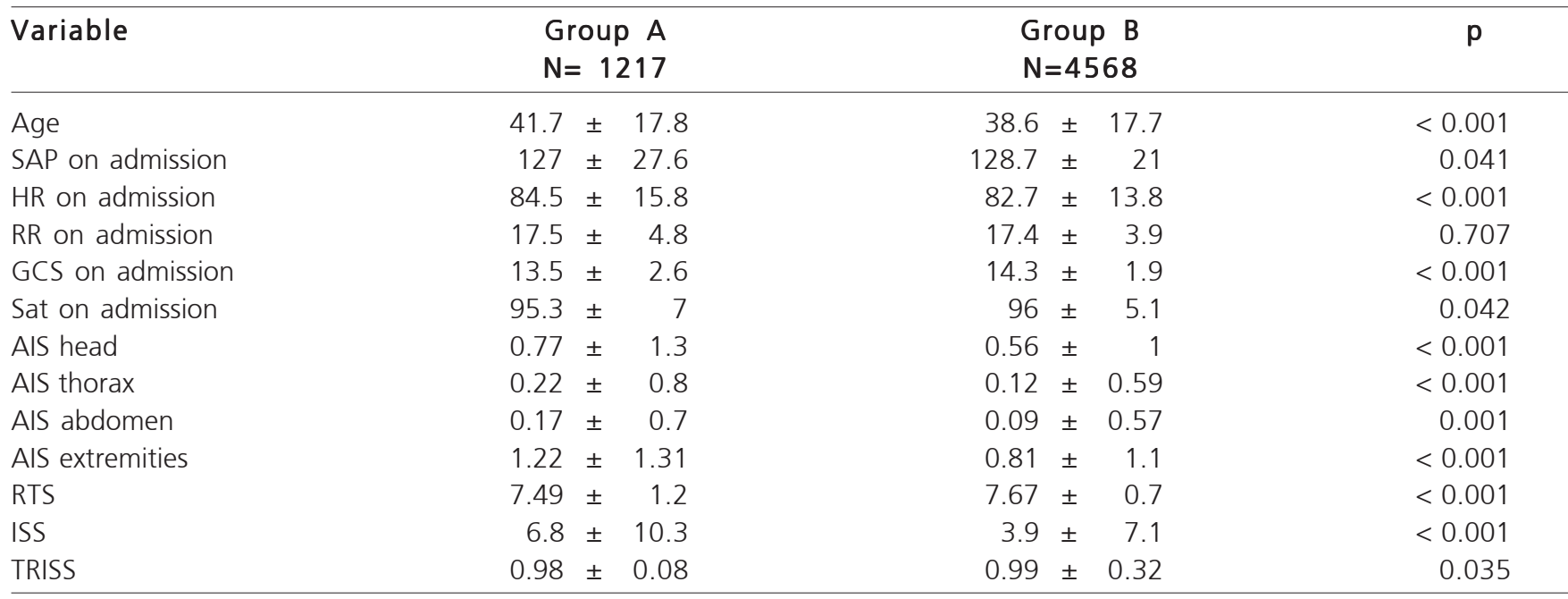

Source: Serviço de Emergência da Irmandade da Santa Casa de Misericórdia de São Paulo (2008-2013).

Age in years; SAP, Systolic Arterial Pressure in millimeters of mercury; RR, respiratory rate in breaths per minute; HR, heart rate in beats per minute; GCS, Glasgow coma scale; Sat, Oxygen saturation, in percentage; AIS, Abbreviated Injury Scale; RTS, Revised Trauma Score; ISS, Injury Severity Score; TRISS, calculation of probability of survival in trauma.

Table 3 - Comparison of qualitative variables for Group A (pedestrians struck by vehicles) versus Group B (patients with other mechanisms of blunt trauma).

\begin{tabular}{|c|c|c|c|c|c|}
\hline \multirow{2}{*}{$\begin{array}{l}\text { Variable } \\
\text { Orotracheal intubation }\end{array}$} & \multicolumn{2}{|c|}{$\begin{array}{l}\text { Group } A \\
\mathrm{~N}=1217\end{array}$} & \multicolumn{2}{|c|}{$\begin{array}{l}\text { Group B } \\
\mathrm{N}=4568\end{array}$} & \multirow{2}{*}{$\begin{array}{c}P \\
<0.001\end{array}$} \\
\hline & 65 & $(5.3 \%)$ & 119 & (2.6\%) & \\
\hline Chest drainage & 33 & $(2.7 \%)$ & 60 & $(1.3 \%)$ & 0.001 \\
\hline Extradural hematoma & 30 & $(2.5 \%)$ & 62 & $(1.4 \%)$ & 0.006 \\
\hline Acute subdural hematoma & 67 & $(1.5 \%)$ & 35 & $(2.9 \%)$ & 0.001 \\
\hline Subarachnoid hemorrhaging & 48 & $(3.9 \%)$ & 75 & $(1.6 \%)$ & $<0.001$ \\
\hline Brain contusion & 57 & $(4.7 \%)$ & 98 & $(2.1 \%)$ & $<0.001$ \\
\hline Diffuse axonal injury & 19 & $(1.6 \%)$ & 24 & $(0.5 \%)$ & $<0.001$ \\
\hline Brain Swelling & 18 & $(1.5 \%)$ & 24 & $(0.5 \%)$ & $<0.001$ \\
\hline Craniotomy & 32 & $(2.6 \%)$ & 68 & $(1.5 \%)$ & 0.007 \\
\hline Hemothorax & 26 & $(2.1 \%)$ & 61 & $(1.3 \%)$ & 0.070 \\
\hline Pneumothorax & 31 & $(2.5 \%)$ & 67 & $(1.5 \%)$ & 0.030 \\
\hline Rib fractures & 54 & $(4.4 \%)$ & 109 & $(2.4 \%)$ & $<0.001$ \\
\hline Flail chest & 26 & $(2.1 \%)$ & 31 & $(0.7 \%)$ & $<0.001$ \\
\hline Lung contusion & 36 & $(3 \%)$ & 55 & $(1.3 \%)$ & $<0.001$ \\
\hline Pelvic fracture & 42 & (3.5\%) & 50 & $(1.1 \%)$ & $<0.001$ \\
\hline Upper limb fracture & 77 & $(6.3 \%)$ & 188 & $(4.1 \%)$ & 0.005 \\
\hline Lower limb fracture & 107 & (8.8\%) & 190 & $(4.2 \%)$ & $<0.001$ \\
\hline Upper limb open fracture & 10 & $(0.8 \%)$ & 51 & $(1.1 \%)$ & 0.37 \\
\hline Lower limb open fracture & 63 & $(5.2 \%)$ & 99 & $(2.2 \%)$ & $<0.001$ \\
\hline Lethality & 52 & $(4.3 \%)$ & 69 & $(1.5 \%)$ & $<0.001$ \\
\hline
\end{tabular}

Source: Serviço de Emergência da Irmandade da Santa Casa de Misericórdia de São Paulo (2008-2013).

correlated with pedestrian trauma. Generally, in rural areas there is less signage and abidance with traffic laws ${ }^{13}$. Vehicle type and design are also associated with pedestrian patient outcomes. Countries such as the USA, where there is culture of using pick-up type automobiles, tend to have higher impact trauma compared to European countries, in which urban compact automobiles predominate ${ }^{14,15}$. The most severe traumas typically occur at nighttime when visibility 
on the roads is poorer. Associated factors such as higher rate of drunkenness, whether among drivers or pedestrians, clearly contributes to this statistic ${ }^{16}$

Based on the data analyzed in the present study, vehicle-pedestrian accidents were responsible for $21 \%$ of the blunt trauma cases seen at the central emergency room of the Santa Casa de Misericórdia de São Paulo hospital. This rate is comparable with the figure of $20 \%$ published by DATASUS ${ }^{3}$ and represents the second-most-common mechanism of trauma seen at the service after motorcyclists. It is noteworthy that the majority of vehicle-pedestrian accidents result from breaches of safety such as crossing the street without using pedestrian crossings and also imprudence by drivers. Therefore, preventive measures can play a vital role given the frequency of this trauma mechanism.

There are several factors associated with the severity and prognosis of injured pedestrians ${ }^{17}$. Speed of impact and weight of the vehicle are reported as factors determining poorer prognoses ${ }^{13}$. The risk of a pedestrian sustaining injury with $\mathrm{AIS}>3$ is $10 \%$ at an impact velocity of $17.1 \mathrm{mph}$ yet may be as high as $90 \%$ at $54.6 \mathrm{mph}^{13}$. Greater severity injuries and higher lethality have been reported in pedestrians struck by heavier vehicles such as pick-ups and sports utility vehicles (SUV) ${ }^{15}$.

One of the largest series in the literature highlighted age as one of the major factors related to mortality among pedestrians injured by automobiles ${ }^{8,18}$. Indeed, the influence of age, together with its physiological repercussions and weaker defense reflex mechanism, on morbidity and severity of trauma patients in general has been demonstrated ${ }^{19}$. Injuries in this subgroup are also more severe, especially those involving the head and spinal column. Peng e Bongard, in 1999, showed a relationship between older age and higher ISS on admission, longer hospital stay and greater need for intensive care ${ }^{7}$. Other study has also shown greater injury severity with advancing age $^{18}$. Apparently, lethality is greater in older than younger adults, despite having similar ISS on admission ${ }^{20}$. In the present study, mean age of pedestrians struck by vehicles was higher than that of patients with other mechanisms of blunt trauma. This finding is in line with earlier studies showing that vehicle-pedestrian accidents were the secondmost-common cause of trauma in older-old aged 70 years and over and the leading cause among older adults aged $60-70$ years ${ }^{21}$. The importance of prevention, specifically in this group highly vulnerable to such trauma, is clear.

In the present sample, mean ISS was 6.8 for the pedestrian group, which had lethality of $4.3 \%$. Thus, the majority of patients did not have serious injuries. McElroy et al., in 2013, reported a mean ISS of 12, around double the rate found in the present investigation ${ }^{20}$. Other studies also reported higher injury rates and severity in pedestrian groups compared to the present sample ${ }^{22,23}$. It should be pointed out that the severity of the sample depends essentially on the triage of patients to be attended at a given service. These data suggest, given that Santa Casa is a University Teaching Hospital, there is clearly overtriage of patients, hampering the running of the emergency service as a whole.

Although several studies have analyzed the evolution of pedestrians struck by vehicles, no studies comparing the severity of injuries with other mechanisms of blunt trauma were found. The data of the present study suggests that pedestrians struck by vehicles more frequently sustain certain types of injuries. A higher rate of intracranial injuries (extradural hematomas, acute subdural hematomas, subarachnoid hemorrhage, diffuse axonal injury, Brain Swelling, brain contusion), thoracic injuries (hemothorax, pneumothorax, rib fractures and lung contusion) and injuries to extremities (open and closed fractures) was observed. Pelvic fractures, recognized as a marker of severity in trauma, were also more prevalent in pedestrian patients. Anatomical severity of the trauma was greater for all body segments, evidenced by comparing mean AIS scores. Physiological (RTS) and anatomical (ISS) scales, as well as probability of survival (TRISS) measures, indicated greater trauma severity among this patient group. The pedestrians struck by vehicles exhibited higher mean heart and respiratory rates on admission and also lower mean GCS score. This is associated with the higher rate of orotracheal intubation and chest drainage seen in the pedestrian group compared to the patient group with other blunt trauma mechanisms. These two variables are indicative of greater severity, corroborating previous findings. The direct impact to which pedestrians struck by vehicles are subjected, in the absence of protective equipment, probably leads to potentially more serious injuries. This finding closely mirrors the data reported in both national and international literature $22-27$

The knowledge that pedestrians struck by vehicles have specific characteristics, differentiating them from patients with other trauma mechanisms, is important from a clinical and epidemiological standpoint. Besides being the second-most-common mechanism of blunt trauma in the Brazilian milieu, vehicle strikes are potentially more serious than other mechanisms and affect older age groups. This warrants special attention from authorities. When dealing with a pedestrian struck by a vehicle, firstresponders should be alert to the greater likelihood of severe injuries and physiological decompensation requiring immediate invasive procedures in the trauma room. A high level of suspicion for internal injuries, especially TBI and thoracic injuries should guide complementary exams. This information is also useful for the pre-hospital care and stabilization teams, since triage of these patients should take into account the greater severity associated with this type of trauma mechanism. Epidemiologically, wide discussion is necessary for the implementation of preventive measures, since this constitutes a potentially avoidable mechanism, yet one that is associated with greater risk of hospitalization, invasive procedures and death. 
In conclusion, pedestrians struck by vehicles have a higher rate and severity of intracranial, thoracic, abdomi- nal and extremity injuries compared to patients with other mechanisms of blunt trauma.

\section{R E S U M O}

Objetivo: comparar, entre vítimas de atropelamento e de outros mecanismos de trauma fechado, a frequência e gravidade das lesões identificadas. Métodos: análise retrospectiva das informações do registro de trauma, incluindo as vítimas de trauma fechado, com idade superior a 13 anos de idade, admitidas entre 2008-2010. Avaliamos o mecanismo de trauma, dados vitais à admissão e lesões diagnosticadas. A estratificação de gravidade da amostra foi realizada pelos índices RTS, AIS-90, ISS e TRISS. As vítimas de trauma fechado foram separadas em dois grupos: Grupo A-pedestres vítimas de atropelamento; Grupo B-vítimas dos demais mecanismos de trauma fechado. As variáveis foram comparadas entre os dois grupos. Resultados: foram incluídos no estudo 5785 casos, sendo que, 1217 (21,0\%) foram vítimas de atropelamento. Observamos que os traumatizados do grupo $A$ apresentaram, significativamente $(p<0,05)$, maior média etária, de frequência cardíaca à admissão, de ISS, de AIS no segmento cefálico, torácico, abdominal e em extremidades, bem como, menor média de escala de coma de Glasgow, pressão arterial sistólica a admissão, RTS e TRISS. As vítimas de atropelamento também apresentaram $(p<0,05)$, maior frequência de hematomas extradurais, hematomas subdurais agudos, hemorragia subaracnoidea, Brain Swelling, contusão cerebral, lesão axonal difusa, fraturas de arcos costais, pneumotórax, tórax flácido, contusão pulmonar, bem como, fraturas de pelve, de membros superiores, inferiores e expostas de membros inferiores. Conclusão: as vítimas de atropelamento apresentam maior frequência e gravidade de lesões intracranianas, torácicas, abdominais e em extremidades quando comparadas às vítimas de outros mecanismos de trauma fechado em conjunto.

Descritores: Acidentes de Trânsito. Traumatismo Múltiplo. Índices de Gravidade do Trauma. Prevenção de Acidentes. Ferimentos e Lesões.

\section{REFERENCES}

1. Lozano R, Naghavi M, Foreman K, Lim S, Shibuya K, aboyans V, et al. Global and regional mortality from 235 causes of death for 20 age groups in 1990 and 2010: a systematic analysis for the global Burden of Disease Study 2010. Lancet. 2012;380(9859):2095-128. Erratum in: Lancet. 2013;381(9867):628.

2. Global status report on road safety - 2013: Supporting the Decade. Geneva: World Health Organization; 2013. [acesso em: 12 jul 2014]. Disponível em: http://journalistsresource.org/studies/environment/ transportation/road-safety-motor-vehicle-accidents-surveying-global-us-data\#sthash.fErNhzJw.dpuf.

3. Brasil. Ministério da Saúde. Datasus. Tecnologia da Informação a Serviço do SUS. Óbitos por causas externas - Brasil 2011 [acesso em: 12 jul 2014]. Disponível em: http://tabnet.datasus.gov.br/cgi/ tabcgi.exe?sim/cnv/ext10uf.def.

4. Denatran: Departamento Nacional de Trânsito. Brasília (DF): Sistema Nacional de Registro de Veículos. 2013 [acesso em 12 jul 2014]. Disponível em: http://www.denatran.gov.br/frota.htm.

5. Bacchieri G, Barros AJD. Acidentes de trânsito no Brasil de 1998 2010: muitas mudanças e poucos resultados. Rev Saúde Pública. 2011;45(5):949-63.

6. Derlet RW, Silva J Jr, Holcroft J. Pedestrian accidents: adult and pediatric injuries. J Emerg Med.1989;7(1):5-8.

7. Peng RY, Bongard FS. Pedestrian versus motor vehicle accidents: an analysis of 5,000 patients. J Am Coll Surg.1999;189(4):343-8.

8. Hefny AF, Eid HO, Abu-Zidan FM. Pedestrian injuries in the United Arab Emirates. Int J Inj Contr Saf Promot. 2014 Apr 10. [Epub ahead of print]

9. Champion HR, Sacco WJ, Copes WS, Gann DS, Gennarelli TA, Flanagan ME. A revision of the Trauma Score. J Trauma.1989;29(5):623-9.

10. Association for Advancement of Automotive Medicine (AAAM). The Abbreviated Injury Scale (AIS). A brief introduction. 1990 Revision. Illinois, USA: AAAM; 1998.
11. Baker SP, O'Neill B, Haddon W Jr, Long WB. The injury severity score: a method for describing patients with multiple injuries and evaluating emergency care. J Trauma.1974;14(3):187-96.

12. Boyd CR, Tolson MA, Copes WS. Evaluating trauma care: the TRISS method. Trauma Score and the Injury Severity Score. J Trauma. 1987;27(4):370-8.

13. Kim JK, Ulfarsson GF, Shankar VN, Kim S. Age and pedestrian injury severity in motor-vehicle crashes: a heteroskedastic logit analysis. Accid Anal Prev. 2008;40(5):1695-702.

14. Matsui Y. Effects of vehicle bumper height and impact velocity on type of lower extremity injury in vehicle-pedestrian accidents. Accid Anal Prev. 2005;37(4):633-40.

15. Ballesteros MF, Dischinger PC, Langenberg P. Pedestrian injuries and vehicle type in Maryland, 1995-1999. Accid Anal Prev. 2004:36(1):73-81.

16. Tefft BC. Impact speed and a pedestrian's risk of severe injury or death. Accid Anal Prev. 2013:50:871-8.

17. Matsui $Y$, Oikawa S, Ando K. Risks of pedestrian serious injuries and fatalities associated with impact velocities of cars in car-versuspedestrian accidents in Japan. Stapp Car Crash J. 2013;57:20117

18. Demetriades D, Murray J, Martin M, Velmahos G, Salim A, Alo K, et al. Pedestrians injured by automobiles: relationship of age to injury type and severity. J Am Coll Surg. 2004;199(3):382-7.

19. Demetriades D, Sava J, Alo K, Newton E, Velmahos GC, Murray $\mathrm{JA}$, et al. Old age as a criterion for trauma team activation. J Trauma. 2001;51(4):754-6; discussion 756-7.

20. McElroy LM, Juern JJ, Bertleson A, Xiang Q, Szabo A, Weigelt J. A single urban center experience with adult pedestrians struck by motor vehicles. WMJ. 2013;112(3):117-22.

21. Parreira JG, Farrath S, Soldá SC, Perlingeiro JAG, Assef JC. Análise comparativa das características do trauma entre idosos com idade superior e inferior a 80 anos. Rev Col Bras Cir. 2013;40(4):26974.

22. Desapriya E, Subzwari S, Sasges D, Basic A, Alidina A, Turcotte K, et al. Do light truck vehicles (LTV) impose greater risk of pedestrian 
injury than passenger cars? A meta-analysis and systematic review. Traffic Inj Prev. 2010;11(1):48-56.

23. Roudsari BS, Mock CN, Kaufman R. An evaluation of the association between vehicle type and the source and severity of pedestrian injuries. Traffic Inj Prev. 2005;6(2):185-92.

24. Scalassara MB, Souza RKT, Soares DFPP. Características da mortalidade por acidentes de trânsito em localidade da região sul do Brasil. Rev Saúde Pública. 1998;32(2):125-32.

25. Soares DFPP, Soares DA. Características das vítimas pedestres traumatizadas em acidente de trânsito em Maringá - PR. Ciênc cuid saúde. 2002;1(1):61-5.

26. Soares DFPP, Barros MBA. Fatores associados ao risco de internação por acidentes de trânsito no Município de Maringá-PR. Rev bras epidemiol. 2006;9(2):193-205.
27. Reichenheim $M E$, de Souza ER, Moraes $C L$, de Mello Jorge $M H$, da Silva CM, de Souza Minayo MC. Violence and injuries in Brazil: the effect, progress made, and challenges ahead. Lancet. 2011;377(9781):1962-75.

Received on 18/01/2015

Accepted for publication 27/03/2015

Conflict of interest: none.

Source of funding: none.

Address for correspondence:

José Gustavo Parreira

E-mail: jgparreira@uol.com.br 